EPRA International Journal of Economic and Business Review-Peer Reviewed Journal

Volume - 9, Issue - 12, December 2021 | e-ISSN: 2347 - 9671| p- ISSN: 2349 - 0187

\title{
AN ANALYTICAL STUDY OF TAXATION LITERACY AMONG INDIVIDUALS
}

\author{
Dr. Mridula Singhal ${ }^{1}$, Ankit Verma ${ }^{2}$ \\ ${ }^{1}$ Associate Professor, Department of Applied Business Economics, Faculty of Commerce, Raja \\ Balwant Singh College, Agra, U.P., India
}

${ }^{2}$ Research Scholar, Department of Applied Business Economics, Faculty of Commerce, Raja Balwant Singh College, Agra, U.P., India

Over the recent years, taxation literacy has become a major area of concern for governments, banks, community service groups, other similar organizations, and people in India. People largely lack basic knowledge about financial matters, required to take household decisions, day-to-day money management as well as saving for the long term. Taxation literacy is defined as the knowledge which an individual should possess to manage the issues concerning personal taxation effectively. It helps the individuals in assessing their tax liability, tax management, and tax planning too. Lack of financial and taxation literacy often makes people vulnerable to a financial crisis. It also adversely affects market operations and competitive forces. On the other hand, people who are well informed and well knowledgeable can help to create a more competitive and more efficient financial and tax planning system.

The basic purpose of this study is to determine the relationship between financial and taxation literacy among the people, the impact of various government awareness programs on salaried individuals. An illiterate person may arise issues related to tax evasion which is illegal in Indian perspectives. Descriptive type of research will be used to describe the meaning of taxation literacy and review various research papers. Data will be collected from secondary sources. The later section of this review paper observes the views of the different researchers on taxation literacy and will give valued suggestions and future viewpoints on the same.

KEYWORDS: Taxation Literacy, Financial Literacy, Tax Management, Tax Planning, People

\section{INTRODUCTION}

Tax literacy is as relevant for any individual as financial literacy. There are the major elements of tax literacy that help us in driving a conclusion i.e., Tax awareness, Contextual Knowledge, and Skills. Tax literacy can be defined as the knowledge which a person must possess to manage the problems concerning personal taxation effectively. Tax awareness means information relating to taxation laws and incidence of taxes i.e., levy on a specified income and liable to pay tax on such income. Contextual knowledge simply means the understanding level of tax laws and able to mobilize the same to understand a situation. It is implicit. To tackle the issues relating to tax management, the taxpayer must be aware as well as able to understand basic concepts of tax. In this context, the tax literacy of an individual plays an important role. Assesses should also be aware of his/her available exemptions and deductions to get a benefit from it. People should be able to differentiate between tax avoidance and tax evasion. Skills of person are also required in managing tax compliances e.g., tax 
management and filing various tax returns. It also helps to avoid interest, penalties, etc. The basic purpose of this study is to determine the relationship between financial and taxation literacy among the people, the impact of various government awareness programs on salaried individuals. Evaluating the level of tax knowledge among salaried persons will help us to see the actual level of tax knowledge possessed by them. We will also be able to govern the factors which significantly impact the level of tax literacy. Tax knowledge combines information about tax rules and tax policies with financial skills needed in the calculation of economic consequences for taxpayers.

Tax literate people easily understand the tax laws and can plan their financial planning efficiently. Tax literacy might be defined as the knowledge which one must have to manage the problems concerning personal taxation effectively. The major focus of this study is to examine the awareness level among individuals about various available deductions and exemptions and analyze the relationship between taxation literacy and financial literacy. This study also examines the role of taxation literacy in tax management and also measures the relationship between taxation literacy and tax planning.

\section{OBJECTIVES}

The followings are the main objectives of this study

- To determine the relationship between financial and taxation literacy among the people.

- To explore the relationship between taxation literacy, tax planning, and tax management.

- To review the research literature on financial and taxation literacy.

- To find and analyze the areas of research gaps in taxation literacy.

- To give recommendations for fulfilling the research gaps.

\section{RESEARCH METHODOLOGY}

This paper is an attempt at exploratory research and descriptive. Data is collected from secondary sources i.e., magazines, publications, articles, research papers, and E-journals, etc.

\section{LITERATURE REVIEW}

Various studies have been conducted from time to time across the world on financial and taxation literacy and tax planning decision-making.

- Bornman, M., and Wassermann, M. (2020) in their study "Tax Knowledge for the Digital Economy", conclude that in the digital economy they require unique tax knowledge and also need to encourage ICT-based knowledge among individuals.

- Singhal, M., and Singh, A. (2020) found in the study that there is a positive relationship between financial literacy and savings of households. Demographic variables and socio-economic variables also affect the financial literacy rate,

- Hastings, J., and Mitchell, O. S. (2020) in their paper conclude that the measure of impatience is a strong predictor of wealth and investment in health. Financial literacy is also interrelated with wealth though it seems to be a weaker predictor of sensitivity to framing in investment decisions.

- Gajendra, N. (2017) in his paper concludes that the Low level of financial literacy prevents individuals from making the right choices regarding financial decisions. He also concludes that Indian people are financially illiterate.

- Oladipupo, A. O., and Obazee, U. (2016) in their study "Tax Knowledge, Penalties and Tax Compliances in Small and Medium Scale Enterprises in Nigeria" determines that tax knowledge is positively related to tax compliance and negatively related to a tax penalty.

- Bharat, T., and Surendra, N. (2015) conclude the paper that students have a basic level of financial knowledge, but they lack an understanding of credit, taxes, share market, financial statement, and insurance. Students are extremely influenced by their parents and have a positive attitude towards savings. They also conclude that financial knowledge is not related to gender, university affiliation, financial behavior, and influence.

- Jaroslav Kovarnik, E. H. (2015) observes that most of the taxpayers were consider the tax system is inequitable in the Czech Republic. The basic element of this inequity is vertical and horizontal, as well as in the failure of legislative framework both during the creation and application of tax laws. The level of awareness among the general public related to tax laws is comparatively low.

- Gowri., (2014) concludes that, the level of financial literacy among the youth employees, the determinants of their financial literacy, the sources of financial matters, the challenges they meet, and their attitude and behavior in obtaining their financial goals.

- Puneet, B., (2014) states that financial literacy plays an important role in individuals' level of understanding in their financial matters and financial planning. Financial literacy also makes an 
individual effective while choosing financial products and services by evaluating associated risk and return with it. The researcher also recommends that the financial literacy level of individuals affects the awareness as well as investment preferences of salaried people towards financial products.

- Sobhesh, K., and Agarwalla, (2013) in their paper conclude that socio-demographic factors and income of individuals, gender, and their education influence different dimensions of financial literacy among the working young in urban India. The study provides an analytical basis for enunciating policy for enhancing the financial literacy of youth in India.

- Chaturvedi and Khare, (2012) investigate the investment pattern and awareness of Indian investors while they invest their money in different investment instruments. Results of the study suggest that the age, education, and income level of an individual affect their investment behavior. The awareness level towards traditional investment options is much higher than that for modern investment options.

- Girdhari and Satya, (2011) examine the investment preference of individuals belonging to Orissa. In their study, they found that investment decisions and risk tolerance of investors were affected by demographic factors.

- Sandra j. Huston, (2010) in his paper concludes that to understand financial literacy and to select the best alternative from various alternatives, it is essential to know the appropriate meaning and effective measures while measuring financial literacy.

- Lusardi, A, Mitchell, Olivia, C., (2009) in their study "Financial literacy among the young: evidence and implications for consumer policy" concludes that financial literacy is low; less than one-third of young adults possess basic knowledge of interest rates, inflation, and risk diversification. And sociodemographic features and family financial status are strongly related to financial literacy.

- Ibrahim et al., (2008) examine gender differences in tolerance of risk. They also studied the impact of knowledge and experience on financial risk tolerance. Their results show that women are less risktolerant than men. They also conclude that financial risk tolerance is affected by knowledge as well as experience in the field of finance.

- Haberman, S. M., (2007) in his paper "Teen Financial Knowledge, Self-Efficacy, and Behaviour: A Gendered View. Financial Counselling and Planning Education" concluded that there is a positive relationship between female respondents and financial literacy and planning for future investment decisions and the relationship is inverse with male candidates.

- Ahmad Razman Abdul Latiff, B.A., (2005) in their paper concludes that professional has the highest percentage of knowledge than the respondents. In the comparison of businessmen and officers, businessmen avail services to file tax, and officers do not avail it.

- Singh, (2003) has provided evidence that shows that there is a very close relationship between tax knowledge and assesses the ability to understand tax laws and also able to comply with them.

- Chattopadhaya and Das Gupta, (2002) focused on the influence of compliance cost on an individual's compliance behavior. The major observation of their study is that there seems to be a relationship between some components of compliance cost, including bribes, and compliance which hurt tax revenue. The compliance costs may be positively affecting compliances, whereas bribes and the use of tax advisors may negatively affect compliances.

- Kasipillai, (2002) observed that tax knowledge is a major component of the involuntary tax compliance system, otherwise it makes it difficult to comply with tax laws.

- Ericksen and Fallan, (1996) claimed in their study that preferences and attitudes towards taxation are dependent upon tax knowledge about tax laws. They also emphasized the importance of tax knowledge in a tax system. They suggested that there is an association between attitude and fiscal knowledge towards taxation and tax behavior. Tax compliances are also managed by a better understanding of tax laws.

- Coolins, Milliron and Toy, (1992) conclude that tax knowledge and education level were inversely correlated with compliance behavior. They also found that knowing tax laws is important for preferences and attitudes towards taxation.

- Harris, (1989) in his study classify respondents' knowledge into two categories i.e., the knowledge that has been received through the formal education system and knowledge precisely directed at possible opportunities to tax evasion.

- Lewis, (1982) studied the impact of increased tax knowledge on attitude towards taxation which might have a substantial impact on tax compliances. He also concludes that there is irrelevant knowledge about tax laws because of these people's non-compliance behavior. He also concludes that a low level of tax knowledge is related to a negative attitude towards tax. 


\section{CONCLUSION}

According to the review of the literature done so far, we can conclude the main points as follows:

- Taxation literacy is an integral part of financial literacy and both play a vital role while planning for tax and its management. Females are more literate than males in respect of both finances and taxes.

- It's also concluding that more financially literate people will lead to a rise in the taxation literacy rate.

- There is a positive relationship between taxation literacy and tax planning and tax management too.

- Role of professional people and information communication technology acting an important role in making people aware.

\section{RESEARCH GAP AND RECOMMENDATIONS FOR FUTURE RESEARCH}

The gaps provide potential future research opportunities in the following areas:

- A careful review of the existing literature in the area of financial and taxation literacy reveals that very few studies have focused on the relationship between taxation literacy and the investment preferences of individuals.

- More research is needed to understand how the financial and taxation literacy level awareness about products are available for investment purposes.

- Another area for taxation literacy that needs more focus is tax planning and its management.

- Retirement planning and its association with taxation literacy of people is another important aspect where more studies are required in India.

Recommendations for government policymakers and individuals for fulfilling the research gaps in taxation literacy:

- Need to study certain factors i.e., demographic, gender and psychographic variables should also consider while studying the level of taxation literacy.

- More research is needed for getting insights into the basic construct and its impacts on tax planning.

- Need to study the impact of the government's initiative on people to be aware of tax laws and available deductions and benefits of exemptions while planning for their tax liability.

- Taxation literacy should be a part of adult education programs.

- The government and other regulatory agencies should also make taxation systems and awareness programs for taxation literacy easier for the common men.

\section{REFERENCES}

1. Bornman, M., and Wassermann, M. (2020). "Tax knowledge for the digital economy". Journal of Economic and Financial Sciences, Volume 13(1), Page No.1-11.

2. Chattopadhyay, S., and Das-Gupta, A. (2002). "The compliance cost of the personal income tax and its determinants". National Institute of Public Finance and Policy, New Delhi.

3. Chattopadhyay, S., and Das-Gupta, A. (2002). "The income tax compliance cost of Indian corporations". National Institute of Public Finance and Policy, New Delhi

4. Chattopadhyay, S., and Das-Gupta, A. (2002). "The personal income tax in India: Compliance costs and compliance behavior of taxpayers". National Institute of Public Finance and Policy, New Delhi.

5. Chaturvedi, M., and Khare, S. (2012). "Study of saving pattern and investment preferences of individual households in India". International Journal of Research in Commerce and Management, Volume 3(5), Page No. 115-120.

6. Collins, J. H., Milliron, V. C., and Toy, D. R. (1992). "Determinants of tax compliance: A contingency approach". The Journal of the American Taxation Association, Volume 14(2), Page No. 1.

7. Eriksen, K., and Fallan, L. (1996)." Tax knowledge and attitudes towards taxation; A report on a quasiexperiment". Journal of economic psychology, Volume 17(3), Page No. 387-402

8. Gajendra, N. (2017). "Financial literacy in India: A review of the literature". International Journal of Research in Business Studies and Management, Volume 4(6), Page No. 30-32.

9. Girdhari, M., and Sathya, S. D. (2011). "A study on investment preferences among urban investors in Orrisa”. Prerna-Journal of Management Thoughts and Practices, Volume 3(1), Page No. 19.

10. Gowri. (2014). "A study on financial literacy among young employees in Coimbatore city". Working Paper, Page No. 1-8.

11. Graber, J. G. (2020). "Financial literacy and retirement planning education: A quantitative analysis of perceived and actual knowledge by information source". Wilmington University (Delaware).

12. Haberman, S. M. (2007). "Teen financial knowledge, self-efficacy, and behavior: A gendered view". Financial Counselling and Planning Education, Volume 18, Issue 2, Page No. 48-60.

13. Harris, T. S., and Kemsley, D. (1999). "Dividend taxation in firm valuation: New evidence". Journal of Accounting Research, Volume 37(2), Page No. 275-291.

14. https://en.wikipedia.org/wiki/Income_tax_in_India

15. https://en.wikipedia.org/wiki/Tax 
16. Kasipillai, J. (2002). "Investigations and tax audit under the self-assessment system”. The Company Secretary Malaysia, Page No. 16-22.

17. Latiff, A. R. A., Noordin, B. A. A., Omar, M. R. C., and Harjito, D. A. (2005)." The tax literacy rate among taxpayers: Evidence from Malaysia”. Journal Akuntansi dan Auditing Indonesia, Volume 9(1).

18. Lewis, A. (1982). "The psychology of taxation". Blackwell.

19. Oladipupo, A. O., and Obazee, U. (2016). "Tax knowledge, penalties, and tax compliance in small and medium scale enterprises in Nigeria”. Business, Volume 8(1), Page No. 1-9.

20. Palil, M. R. (2010). "Tax knowledge and tax compliance determinants in self-assessment system in Malaysia”. Doctoral dissertation, University of Birmingham.

21. Puneet, B., (2014). "Relationship between financial literacy and investment behavior of salaried individuals". Journal of Business Management and Social Sciences Research, Volume 3(5), Page No. 82-87.

22. Sandra j. Huston, (2010). “Measuring financial literacy”. the journal of Consumer Affairs, Volume 44(2), Page No. 296-316.

23. Singhal, M., and Singh, A. (2020). "Factors contributing to the financial literacy of individual: A critical literature review”. Pen Acclaims, Volume 8.

24. Sobhesh, K., Agarwalla, (2013). “Financial literacy among working young in urban India”. Indian Institute of Management, Page No. 1-27.

25. Thapa, B. S. (2015). "Financial literacy in Nepal: A survey analysis from college students". NRB Economic Review, Volume 27(1), Page No. 49-74.

26. Vosilov, R., and Ali Ibrahim, A. (2008). "Financial risk tolerance: Differences between women and men”. 